\title{
Liming and application of micronutrients in the establishment of Tifton pasture
}

\section{Calagem e aplicação de micronutrientes na implantação de pastagem de Tifton}

\section{Luciano Colpo GATIBONI'; Rodrigo PREDEBON²; Clovisson Menotti Boeira de OLIVEIRA ${ }^{3}$; Paulo Roberto ERNANI ${ }^{1}$; Djalma Eugênio SCHMITT'; ${ }^{4}$ Paulo Cezar CASSOL1}

\author{
${ }^{1}$ Doutores, Professores da Universidade do Estado de Santa Catarina - (UDESC). E-mail: Igatiboni@gmail.com; \\ paulorobertoernani@gmail.com \\ ${ }^{2}$ Mestre em ciência do Solo, Professor do Instituto Federal de Educação, Ciência e Tecnologia do Paraná-(IFPR). \\ Email:rodrigopredebon@yahoo.com.br \\ ${ }^{3}$ Doutor em Ciência do Solo, Professor do Instituto Federal Catarinense - Campus Rio do Sul. E-mail: \\ clovissonboeira@yahoo.com.br \\ ${ }^{4}$ Autor para correspondência - Doutor em Ciência do Solo, Bolsista de Pós Doutorado em Ciência do Solo da Universidade do \\ Estado de Santa Catarina - (UDESC), Av. Luis de Camões, 2090, Lages (SC), Cep: 88520-000. E-mail: \\ djalma.schmitt@gmail.com
}

Recebido em: 30-09-2016; Aceito em: 08-06-2017

\begin{abstract}
Tifton pastures (Cynodon spp.) are widely used in tropical regions of Brazil, but are relatively recent in sub-tropical soils of southern Brazil. The objective of this work was to evaluate the Tifton response to liming and fertilization with copper $(\mathrm{Cu})$, zinc $(\mathrm{Zn})$ and boron $(\mathrm{B})$ in the pasture establishment in the state of Santa Catarina. The experiment was installed in a Rhodic Ferralsol, in a randomized block design with subdivided plots. The treatments consisted of limestone doses in the main plots and application or non-application of $\mathrm{Cu}, \mathrm{Zn}$ and $\mathrm{B}$ in the subplots. The doses tested were $4.25 \mathrm{t} \mathrm{ha}^{-1}$ limestone (half the recommended dose to raise the $\mathrm{pH}\left(\mathrm{H}_{2} \mathrm{O}\right)$ to 5.5$)$; $8.5 \mathrm{t} \mathrm{ha}^{-1}$ (dose to raise the $\mathrm{pH}\left(\mathrm{H}_{2} \mathrm{O}\right)$ to 5.5$) ; 11.9 \mathrm{t} \mathrm{ha}^{-1}$ (dose to raise the $\mathrm{pH}\left(\mathrm{H}_{2} \mathrm{O}\right)$ to 6.0 ) and $15.7 \mathrm{t} \mathrm{ha}^{-1}$ (dose to raise the $\mathrm{pH}\left(\mathrm{H}_{2} \mathrm{O}\right)$ to 6.5$)$, in addition to a treatment without limestone application (control). Micronutrients $\mathrm{Cu}\left(\mathrm{CuSO}_{4}\right), \mathrm{Zn}$ $\left(\mathrm{ZnS}_{4}\right)$ and $\mathrm{B}$ (borax) were applied, respectively, at the doses of 2.0, 2.0 and $1.0 \mathrm{~kg} \mathrm{ha}^{-1}$. In the Tifton establishment, limestone application decreased the values of $\mathrm{Al}$ and $\mathrm{Cu}$ and increased the values of $\mathrm{Ca}, \mathrm{Mg}, \mathrm{pH}$ and soil base saturation. The limestone application in the soil increased the dry matter production of Tifton up to the dose of $8.5 \mathrm{t} \mathrm{ha}^{-1}$, regardless of the application of micronutrients.
\end{abstract}

Additional keywords: acidity correction; boron; copper; perennial pasture; zinc.

\section{Resumo}

As pastagens de Tifton (Cynodon spp) são amplamente utilizadas nas regiões tropicais do Brasil, porém são relativamente recentes nos solos subtropicais sul-brasileiros. $O$ objetivo deste trabalho foi avaliar a resposta do Tifton à calagem e fertilização com cobre $(\mathrm{Cu})$, zinco $(\mathrm{Zn})$ e boro $(\mathrm{B})$, na implantação da pastagem no Estado de Santa Catarina. O experimento foi instalado em um Latossolo Vermelho, em delineamento de blocos casualizados, com parcelas subdivididas. Os tratamentos constaram de doses de calcário nas parcelas principais e aplicação ou não de $\mathrm{Cu}, \mathrm{Zn}$ e B nas subparcelas. As doses testadas foram de $4,25 \mathrm{t} \mathrm{ha}^{-1}$ de calcário (metade da dose recomendada para elevar o $\mathrm{pH}-\mathrm{H}_{2} \mathrm{O}$ até 5,5); $8,5 \mathrm{t} \mathrm{ha}^{-1}$ (dose para elevar o $\mathrm{pH}-\mathrm{H}_{2} \mathrm{O}$ até 5,5); $11,9 \mathrm{t} \mathrm{ha}^{-1}$ (dose para elevar o $\mathrm{pH}-\mathrm{H}_{2} \mathrm{O}$ até 6,0 ) e $15,7 \mathrm{t} \mathrm{ha}^{-1}$ (dose para elevar $\circ \mathrm{pH}-\mathrm{H}_{2} \mathrm{O}$ até 6,5), além de um tratamento sem aplicação de calcário (testemunha). Os micronutrientes $\mathrm{Cu}\left(\mathrm{CuSO}_{4}\right), \mathrm{Zn}\left(\mathrm{ZnSO}_{4}\right)$ e B (Bórax) foram aplicados nas doses de 2,0, 2,0 e 1,0 kg ha-1. A aplicação de calcário na implantação de Tifton diminuiu os valores de $\mathrm{Al}$ e $\mathrm{Cu}$, e aumentou dos $\mathrm{Ca}, \mathrm{Mg}$, pH e saturação por bases do solo. A aplicação de calcário no solo aumentou a produção de massa seca de Tifton até à dose de 8,5 $\mathrm{t} \mathrm{ha}^{-1}$, independentemente da aplicação de micronutrientes.

Palavras-chave adicionais: boro; cobre; correção da acidez; pastagem perene; zinco.

\section{Introduction}

The state of Santa Catarina is the fifth largest dairy producer in Brazil, with a production of 2,700 thousand liters, with the main dairy basin located in the west region, accounting for $74 \%$ of the state production (EPAGRI, 2013). In this region, cattle feeding is based on pasture, which represents an economic form of production, since it shows adequate climatic condi- tions, without presence of dry season and very rigorous winter, allowing pasture production at all times of the year. In addition to favorable climatic conditions, satisfactory pasture performance requires an adequate nutrient content in the soil and absence of toxic elements such as aluminum (Al) and excess manganese $(\mathrm{Mn})$ in the soil solution.

The soils of the western region of Santa 
Catarina present high clay content, with medium to high organic matter content and acid pH (Ernani \& Almeida, 1986). Therefore, for acidity-sensitive crops, it is essential to apply soil correctives which neutralize soil acidity, thus neutralizing $\mathrm{Al}^{3+}$ and increasing the availability of calcium (Ca) and magnesium (Mg) to plants (Ernani et al., 2002; Kaminski et al., 2005; Volpe et al., 2008). In some cases, the increase of $\mathrm{pH}$ by liming may increase the availability of macronutrients essential for plants, such as phosphorus $(P)$ (Ernani et al., 2001) and nitrogen (N) (Silva \& Vale, 2000), in addition to reducing the availability of some micronutrients (Nascimento et al., 2007). Although some forage species are rustic and adapted to tropical acid soils (Bandinelli et al., 2005), pastures generally do not reach the maximum yield potential due to absence of agronomic techniques such as liming and fertilization.

Micronutrients copper $(\mathrm{Cu})$, zinc $(\mathrm{Zn})$ and boron (B) are adsorbed to soil components (organic matter, oxides, clay minerals) and only a small amount is available to the plants (Nascimento et al., 2007; Garcia et al., 2008; Brunetto et al., 2014). Normally, soils with high clay and organic matter content at their natural $\mathrm{pH}$ present reasonable reserves of these micronutrients that are in equilibrium with the soil solution. However, fertilizer companies have pressured the market for the application of micronutrients, both via soil and foliar, without the use of technical criteria.

The proposed increase in the soil $\mathrm{pH}$ to be reached by the practice of liming is conditioned, among others, to the need of the plant, with plants more or less responsive to liming (Tiecher et al., 2013), and to the buffer power (Gatiboni et al., 2000; CQFS-RS/SC, 2004). However, few studies address the response of pastures with micronutrients (Volpe et al., 2008) and the interaction of these with liming, since in some situations micronutrient deficiency may occur in plants (Impa \& Johnson - Beebout, 2012). Nonetheless, due to the high dry matter production, the export of nutrients, among them micronutrients, is significant (Matos et al., 2010).

The hypotheses of the study are: (I) Liming will increase the $\mathrm{pH}, \mathrm{Ca}$ and $\mathrm{Mg}$ values and, consequently, the dry matter production of Tifton (Cynodon spp); (II) The application of micronutrients will increase the availability of micronutrients and the production of Tifton. The objective of the study was to evaluate the influence of liming and copper, zinc and boron application on the production of Tifton (Cynodon spp.) forage in a Rhodic Ferralsol in southern Brazil.

\section{Material and methods}

The experiment was conducted at the Agricultural School Demétrio Baldissarelli, in the municipality of Chapecó-SC, located at $27^{\circ} 12^{\prime} 40^{\prime \prime}$ South latitude and $52^{\circ} 37^{\prime} 36^{\prime \prime}$ West longitude, with an average altitude of $668 \mathrm{~m}$. The climate of the region is $\mathrm{Cfa}$, mesothermal humid subtropical, according to the Köppen classification. Precipitation and temperature data are presented in Figure 1. The soil of the experimental area is classified as Rhodic Ferralsol (FAO, 1998) and presented the following characteristics for the $0-20 \mathrm{~cm}$ layer before the experiment: $\mathrm{pH}$ (water) $=$ = 4.9; $\mathrm{SMP}$ index $=4.8 ; \mathrm{Ca}^{2+}=3.8 \mathrm{cmol}_{\mathrm{c}} \mathrm{dm}^{-3} ; \mathrm{Mg}^{2+}=$ $=1.2 \mathrm{cmol}_{\mathrm{c}} \mathrm{dm}^{-3} ; \mathrm{Al}^{3+}=3.1 \mathrm{cmol}_{\mathrm{c}} \mathrm{dm}^{-3} ; \mathrm{P}$ (Mehlich-1) = $=7.7 \mathrm{mg} \mathrm{dm}^{-3} ; \mathrm{K}=45.6 \mathrm{mg} \mathrm{dm}^{-3} ; \mathrm{Cu}=1.8 \mathrm{mg} \mathrm{dm}^{-3}$; $\mathrm{Zn}=0.2 \mathrm{mg} \mathrm{dm}^{-3} ; \mathrm{B}=0.2 \mathrm{mg} \mathrm{dm}^{-3}$; Organic Matter = $=75.3 \mathrm{~g} \mathrm{~kg}^{-1}$; Clay $=600 \mathrm{~g} \mathrm{~kg}^{-1}$.

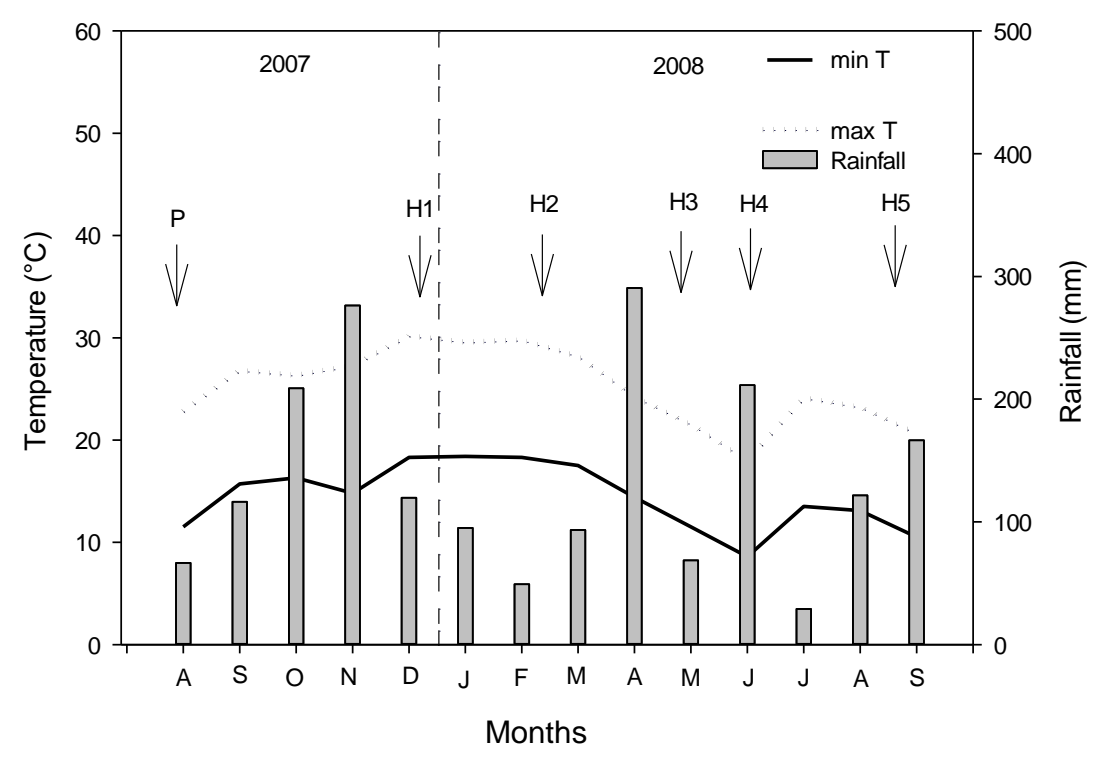

Figure 1 - Rainfall (mm) and maximum average temperature ( $\mathrm{T}$ max) and minimum average temperature (T min) from August 2007 to September 2008 in Chapecó - SC. P - planting; H1 - harvest 1; H2 - harvest 2; H3 - harvest 3; H4 - harvest 4; H5 - harvest 5. 
The experiment was carried out in an area where there was Bermuda grass, which was extinguished with two applications of glyphosate-based herbicide at the dose of $3.0 \mathrm{~L} \mathrm{ha}^{-1}$, performed at 45 and 30 days before planting the seedlings. Subsequently, the soil was plowed with disk plows and leveled with a leveling harrow.

The treatments were set up in a randomized complete block design, under a split-plot arrangement, with four replications. Doses of limestone was allocated to the main plots $\left(24 \mathrm{~m}^{2}\right)$ and application or non-application of micronutrients $(\mathrm{Cu}, \mathrm{Zn}$ and $\mathrm{B})$ to the subplots. The limestone doses tested were $4.25 \mathrm{t} \mathrm{ha}^{-1}$ limestone (half the dose to raise the $\mathrm{pH}\left(\mathrm{H}_{2} \mathrm{O}\right)$ to 5.5); $8.5 \mathrm{t} \mathrm{ha}^{-1}$ (dose to raise the $\mathrm{pH}\left(\mathrm{H}_{2} \mathrm{O}\right)$ to 5.5 , being the recommendation for the crop (CQFS-RS/SC, 2004)); $11.9 \mathrm{tha}^{-1}$ (dose to raise the $\mathrm{pH}\left(\mathrm{H}_{2} \mathrm{O}\right)$ to 6.0 ) and $15.7 \mathrm{t} \mathrm{ha}^{-1}$ (dose to raise the $\mathrm{pH}\left(\mathrm{H}_{2} \mathrm{O}\right)$ to 6.5 ), in addition to a treatment without limestone application (control). Micronutrients $\mathrm{Cu}, \mathrm{Zn}$ and $\mathrm{B}$ were manually applied to the soil (total area) and incorporated, after 30 days of limestone application, at the doses of 2.0, 2.0 and $1.0 \mathrm{~kg} \mathrm{ha}^{-1}$, respectively (Lopes, 1999), having $\mathrm{CuSO}_{4}, \mathrm{ZnSO}_{4}$ and borax as sources. Dolomitic limestone was used, with $82 \%$ based on an acidneutralizing capacity, with half of the dose being applied to the soil surface and incorporated with disk plow, followed by application of the other half of the dose and plowing and harrowing up to $20 \mathrm{~cm}$ depth, 30 days before planting, transversely to the block.

NPK fertilization was carried out in all plots based on the official recommendation (CQFS - RS/SC, 2004), applying $100 \mathrm{~kg} \mathrm{ha}^{-1} \mathrm{P}_{2} \mathrm{O}_{5}, 100 \mathrm{~kg} \mathrm{ha}^{-1} \mathrm{~K}_{2} \mathrm{O}$ at the time of planting, and $400 \mathrm{~kg} \mathrm{ha}^{-1} \mathrm{~N}$, in the form of triple superphosphate, potassium chloride, and urea, respectively. $\mathrm{P}$ and $\mathrm{K}$ were applied on the surface at the moment of planting of the seedlings and incorporated, while the nitrogen was applied in split plots, immediately after the second, third, fourth and fifth pasture harvests (100 kg ha-1 $\mathrm{N}$ in each time).

Tifton 85 seedlings were planted manually on $08 / 19 / 2007$ in a spacing of $0.5 \times 0.5 \mathrm{~m}$. As a result of lack of rainfall after planting the seedlings, the seedling survival and soil cover rate were very low and, therefore, seedlings were replanted 32 days after the first planting. The dry matter yield of the forage was evaluated for 12 months, being analyzed each time the first experimental units reached the average height of $30 \mathrm{~cm}$, which occurred on the following dates: Harvest $1=12-27-2007$, Harvest $2=02-21-2008$, Harvest $3=$ $=04-12-2008$, Harvest $4=05-31-2008$ and Harvest $5=$ $=08-30-2008$. Forage production was determined by cutting at $5 \mathrm{~cm}$ height of three subsamples of $0.25 \mathrm{~m}^{2}$ per plot. After each harvest, the experimental area was immediately mowed and the forage removed from the plots.

The plant material was dried in an air circulation oven at $60{ }^{\circ} \mathrm{C}$ for determination of dry matter production and absorbed amounts of nutrients. The average daily growth (ADG) was calculated by dividing the amount of material harvested per hectare by the number of days of growth until cutting. Soil samples were sampled in the $0-20 \mathrm{~cm}$ layer, after the fifth harvest of the forage, using a Dutch auger. The contents of available $\mathrm{Ca}, \mathrm{Mg}$ and exchangeable $\mathrm{Al}, \mathrm{Cu}$, $\mathrm{Zn}$ and $\mathrm{B}$ were analyzed, in addition to the $\mathrm{pH}\left(\mathrm{CaCl}_{2}\right)$, according to the methodologies described by Tedesco et al. (1995).

The results were submitted to analysis of variance and, when significant, Tukey's mean comparison test $(p<0.05)$ and adjustments of polynomial regression equations were performed. For the choice of the best regression model, we opted for the significant model with the highest degree. For quantitative data, the linear-plateau regression model was used, using SAS software when significant (SAS, 2003).

\section{Results and discussion}

Liming affected growth rate and forage production in the first four harvests, but no effect of micronutrient application or interaction between liming and micronutrient was observed with respect to forage production (Table 1). In the first harvest, the pasture presented a slow growth, since it included the period of pasture establishment, presenting an average daily growth (ADG) of $19.2 \mathrm{~kg} \mathrm{ha}^{-1}$ day $^{-1}$ forage DM (Table 1). Cutting periods 2 and 3 , occurring in the summer, had the highest ADG values, of 76.5 and $62.4 \mathrm{~kg} \mathrm{ha}^{-1}$ day $^{-1}$ DM, respectively. On the other hand, harvests 4 and 5 , in the autumn and winter, presented ADG values of 30.4 and $42.9 \mathrm{~kg} \mathrm{ha}^{-1}$ day $^{-1}$ forage DM, respectively (Table 1). In the last harvest, the pasture showed no response to liming.

For the first four harvests evaluated separately and for the total dry matter production, the response of plants was quadratic to the limestone application in the soil (Figure 2), the maximum yield being obtained with the dose of $9.8 \mathrm{t} \mathrm{ha}^{-1}$, i.e., $15 \%$ above the dose of $8.5 \mathrm{tha}^{-1}$, which is the limestone recommendation to raise the $\mathrm{pH}\left(\mathrm{H}_{2} \mathrm{O}\right)$ to 5.5. At the dose of $8.5 \mathrm{t} \mathrm{ha}^{-1}$, the yield was $99 \%$ of the estimated maximum yield and, at the dose of $4.25 \mathrm{tha}^{-1}$, the yield was $96 \%$ of the estimated maximum yield, indicating that this dose can be recommended. The increase in the dry matter yield by liming may be due to the increase in the levels of $\mathrm{Ca}^{2+}, \mathrm{Mg}^{2+}$, and, consequently, in the values of base saturation (Table 2, Figure $3 \mathrm{~A})$ and $\mathrm{pH}\left(\mathrm{CaCl}_{2}\right)$ (Figure $3 \mathrm{~B})$, in addition to the decrease of $\mathrm{Al}^{3+}$ in the soil (Figure 3b) (Almeida et al., 1999). These improvements in soil chemical quality probably led to an increase in the number of root hairs (Barber, 1984), increasing plant tillering and number of leaves; consequently, the plants absorbed more solar energy, reflecting higher biomass (Prado \& Barion, 2009). 
Table 1.- Variance analysis for Tifton grass dry mass, Tifton dry mass and average daily growth (in parentheses, $\mathrm{kg} \mathrm{ha}^{-1}$ day $^{-1}$ ) over 5 harvests in an Ferralsol with application of lime and micronutrient.

\begin{tabular}{|c|c|c|c|c|c|}
\hline \multirow{3}{*}{ Causes of variation } & \multicolumn{5}{|c|}{ Dry mass (kg ha-1) } \\
\hline & \multicolumn{5}{|c|}{ Harvests } \\
\hline & 1 & 2 & 3 & 4 & 5 \\
\hline \multicolumn{6}{|l|}{ Lime $(\mathrm{L})(\mathrm{t}$ ha-1) } \\
\hline 0.00 & $2,455(18.9)$ & $3,877(69.2)$ & $2,544(50.9)$ & $1,213(25.3)$ & $3,980(46.3)$ \\
\hline 4.25 & $2,267(17.4)$ & $4,230(75.5)$ & $3,080(61.6)$ & $1,568(32.7)$ & $3,311(38.5)$ \\
\hline 8.50 & $2,837(21.8)$ & $4,504(80.5)$ & $3,523(70.5)$ & $1,613(33.6)$ & $3,964(46.1)$ \\
\hline 11.90 & $2,963(22.8)$ & $4,603(82.2)$ & $3,189(63.8)$ & $1,565(32.6)$ & $3,530(41.0)$ \\
\hline 15.70 & $2,352(18.1)$ & $4,208(75.1)$ & $3,251(65.0)$ & $1,337(27.8)$ & $3,677(42.8)$ \\
\hline $\mathrm{F}$ test & $4.39^{*}$ & $8.70^{* *}$ & $8.95^{\star *}$ & $3.58^{*}$ & $0.90 \mathrm{~ns}$ \\
\hline $\mathrm{CV}(\%)$ & 16.1 & 6.4 & 10.9 & 17.9 & 23.1 \\
\hline \multicolumn{6}{|c|}{ Micronutrient $(\mathrm{M})\left(\mathrm{kg} \mathrm{ha}^{-1}\right)$} \\
\hline With & $2,609(20.1)$ & $4,228(75.5)$ & $3,141(62.8)$ & $1,482(30.9)$ & $3,603(41.9)$ \\
\hline Without & $2,541(19.5)$ & $4,343(77.5)$ & $3,093(61.9)$ & $1,436(29.9)$ & $3,784(44.0)$ \\
\hline $\mathrm{F}$ test & $0.28 \mathrm{~ns}$ & $1.62 \mathrm{~ns}$ & $0.19 \mathrm{~ns}$ & $0.43 \mathrm{~ns}$ & $0.94 \mathrm{~ns}$ \\
\hline$L \times M$ & $1.08 \mathrm{~ns}$ & $1.62 \mathrm{~ns}$ & $0.89 \mathrm{~ns}$ & $0.63 \mathrm{~ns}$ & $0.52 \mathrm{~ns}$ \\
\hline CV $(\%)$ & 15.9 & 6.7 & 11.3 & 15.1 & 15.7 \\
\hline
\end{tabular}

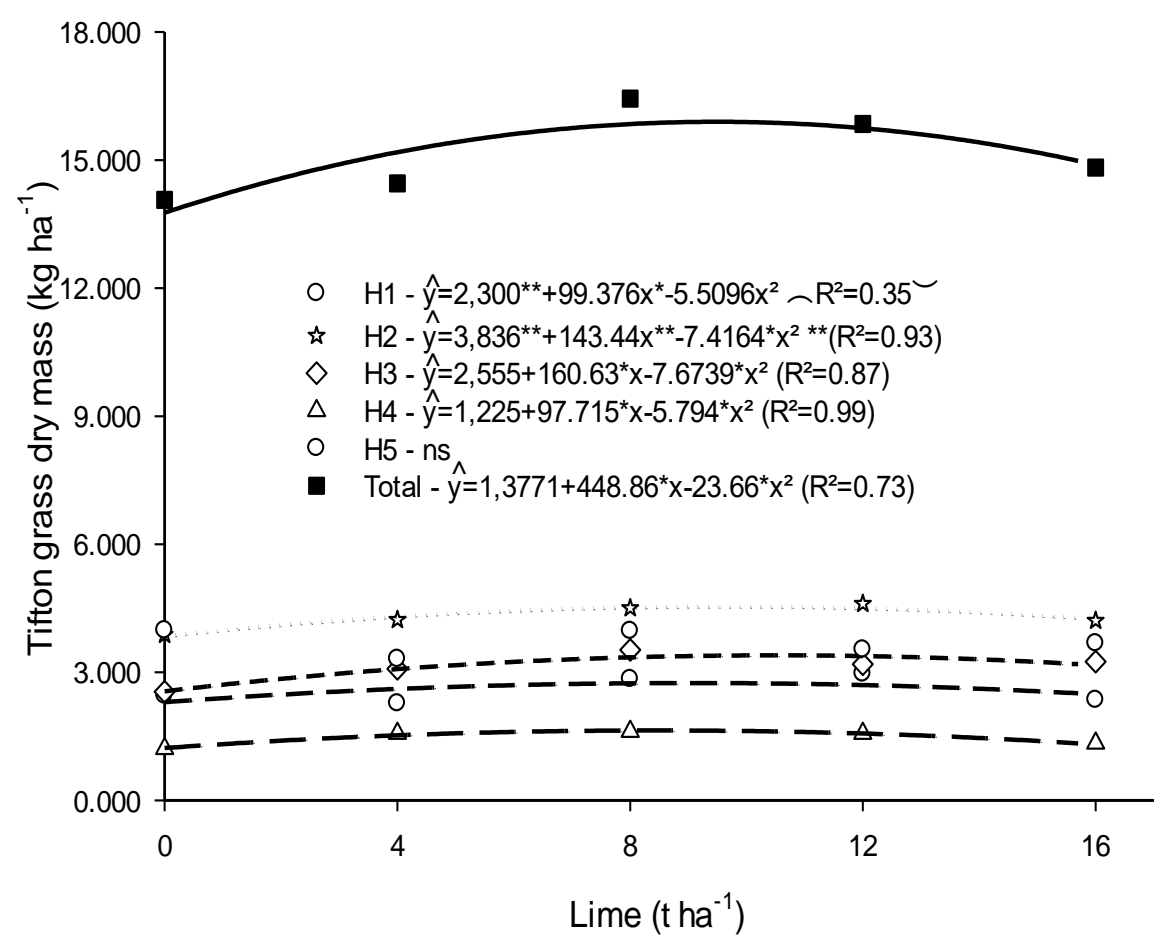

Figure 2 - Tifton grass dry mass in response to application of lime in the soil. $\mathrm{H} 1$ - harvest $1 ; \mathrm{H} 2$ - harvest 2; $\mathrm{H} 3$ - harvest 3; $\mathrm{H} 4$ - harvest 4; $\mathrm{H} 5$ - harvest 5 ; Total - total dry matter.

${ }^{*}$ Significant at $5 \%$ of probability $\mathrm{F}$ test; ** Significant at $1 \%$ of probability; ns - not significant. 

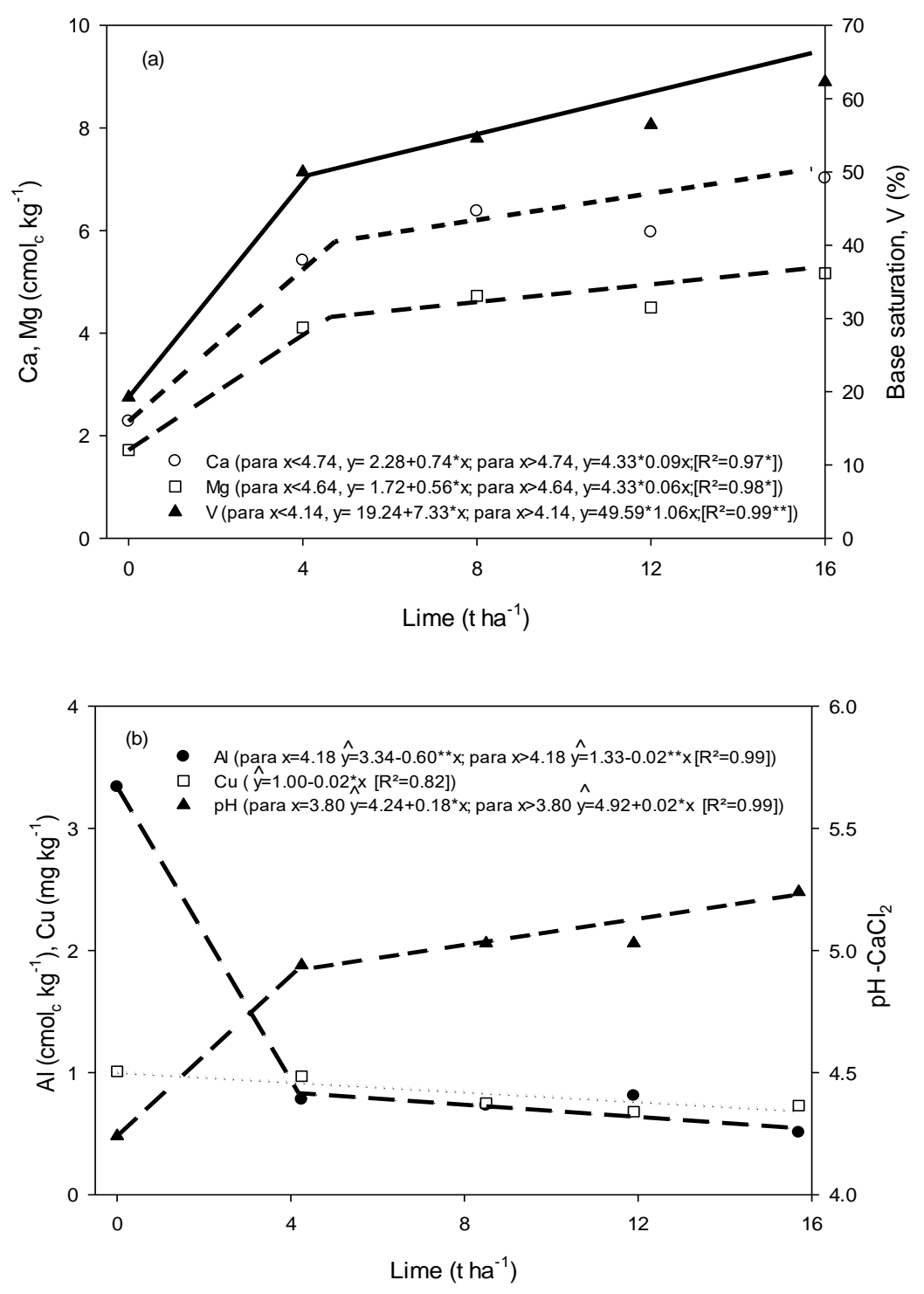

Figure 3 - Calcium and magnesium exchangeable, base saturation (a), $\mathrm{pH}$ in $\mathrm{CaCl}_{2}$, exchangeable aluminum (Al) and available copper $(\mathrm{Cu})(\mathrm{b})$ of Ferralsol in response to application of lime in the soil cultivated with Tifton. ${ }^{*}$ Significant at $5 \%$ of probability $\mathrm{F}$ test; ** Significant at $1 \%$ of probability; ns - not significant.

The application of micronutrients in the soil increased the available contents for all micronutrients (Table 2), but did not affect dry matter production and daily growth (Table 1). The lack of effect of the application of micronutrients $\mathrm{Cu}, \mathrm{Zn}$ and $\mathrm{B}$ on forage production is probably due to the high micronutrient content available in the soil (CQFS-RS/SC, 2004) and the high organic matter content in the $0-20 \mathrm{~cm}$ soil layer $\left(75 \mathrm{~g} \mathrm{~kg}^{-1}\right)$. Hence, with levels above the critical level, the plants did not respond to micronutrient applications (CQFS-RS/SC, 2004). Therefore, even in the case of a plant with a high growth rate and nutrient uptake, micronutrient applications in the soil should only be performed if there is deficiency of availability according to soil analysis following technical criteria (CQFS-RS/SC, 2004).
Except for available $\mathrm{Cu}$, whose decrease in availability was linear with the increase in $\mathrm{pH}$ (Figure $3 b$ ), for the other micronutrients, there was no decrease in availability with increasing liming. This shows that although the increase of soil $\mathrm{pH}$ provided by liming decreases the bioavailable fractions and increases the adsorption (Nascimento et al., 2007) by redistributing these elements into more stable fractions with higher binding energy (Brunetto et al. 2014), the methods used in routine laboratories to evaluate the availability of these micronutrients are not always able to detect these changes (Fonseca et al., 2010). On the other hand, liming causes greater mineralization of organic matter by improving the soil chemical condition for microorganisms (Ernani et al., 2002), which can provide part of the micronutrients that were present in the soil organic matter. 
Table 2 - $\mathrm{pH}$, calcium, magnesium, aluminum, copper, zinc and boron in an Ferralsol with application of lime and micronutrient cultivated with grazing Tifton.

\begin{tabular}{|c|c|c|c|c|c|c|c|c|}
\hline \multirow{2}{*}{ Causes of variation } & \multirow{2}{*}{$\begin{array}{c}\mathrm{pH} \\
\left(\mathrm{CaCl}_{2}\right)\end{array}$} & \multirow{2}{*}{$\begin{array}{c}\mathrm{V} \\
(\%)\end{array}$} & $\mathrm{Ca}$ & $\mathrm{Mg}$ & $\mathrm{Al}$ & $\mathrm{Cu}$ & $\mathrm{Zn}$ & $B$ \\
\hline & & & \multicolumn{3}{|c|}{----- $\left(\mathrm{cmol}_{\mathrm{c}} \mathrm{kg}^{-1}\right)$------ } & \multicolumn{3}{|c|}{$-\cdots\left(\mathrm{mg} \mathrm{kg}^{-1}\right)$} \\
\hline \multicolumn{9}{|l|}{ Lime (L) (t ha-1) } \\
\hline 0.00 & 4.2 & 19.24 & 2.28 & 1.72 & 3.34 & 1.01 & 7.69 & 0.42 \\
\hline 4.25 & 4.9 & 49.98 & 5.42 & 4.11 & 0.78 & 0.97 & 6.88 & 0.29 \\
\hline 8.50 & 5.0 & 54.58 & 6.38 & 4.73 & 0.73 & 0.75 & 6.35 & 0.39 \\
\hline 11.90 & 5.0 & 56.44 & 5.97 & 4.50 & 0.81 & 0.68 & 6.45 & 0.36 \\
\hline 15.70 & 5.2 & 62.28 & 7.02 & 5.17 & 0.51 & 0.73 & 6.29 & 0.31 \\
\hline $\mathrm{F}$ test & $9.48^{\star \star}$ & $13.91^{* *}$ & $17.94^{* *}$ & $22.20^{\star \star}$ & $46.74^{* *}$ & $3.99^{*}$ & $1.02^{\text {ns }}$ & $1.23^{\text {ns }}$ \\
\hline CV (\%) & 7.2 & 26.49 & 22.8 & 20.1 & 39.7 & 26.0 & 24.1 & 40.3 \\
\hline \multicolumn{9}{|c|}{ Micronutrient (M) $\left(\mathrm{kg} \mathrm{ha}^{-1}\right)$} \\
\hline With & 4.9 & 47.83 & 5.25 & 4.05 & 1.30 & $0.95 a$ & $7.50 a$ & $0.40 \mathrm{a}$ \\
\hline Without & 4.9 & 49.17 & 5.58 & 4.04 & 1.17 & $0.70 \mathrm{~b}$ & $5.97 \mathrm{~b}$ & $0.30 \mathrm{~b}$ \\
\hline $\mathrm{F}$ test & $0.02^{\text {ns }}$ & $0.23^{\text {ns }}$ & $1.14^{\mathrm{ns}}$ & $0.00^{\text {ns }}$ & $1.26^{\mathrm{ns}}$ & $17.97^{* *}$ & $22.18^{* *}$ & $12.75^{* *}$ \\
\hline$L \times M$ & $0.44^{\mathrm{ns}}$ & $0.78^{\text {ns }}$ & $0.62^{\text {ns }}$ & $0.66^{\mathrm{ns}}$ & $1.29^{\mathrm{ns}}$ & $1.11^{\mathrm{ns}}$ & $1.49^{n s}$ & $1.78^{\text {ns }}$ \\
\hline CV (\%) & 4.4 & 18.23 & 18.0 & 18.2 & 29.1 & 23.0 & 15.2 & 25.7 \\
\hline
\end{tabular}

$\mathrm{CV}$ - Coefficient of variation; ${ }^{*}$ Significant at $5 \%$ of probability $\mathrm{F}$ test; ${ }^{* *}$ Significant at $1 \%$ of probability; ns - not significant.

For the other soil parameters, two stages of response to liming were observed. In a first moment, the application of limestone at the dose of $4.25 \mathrm{t} \mathrm{ha}^{-1}$ produced a rapid increase of $\mathrm{Ca}^{2+}, \mathrm{Mg}^{2+}, \mathrm{V}$ and $\mathrm{pH}$ $\left(\mathrm{CaCl}_{2}\right)$ and a decrease in exchangeable Al. At doses greater than $4.25 \mathrm{t} \mathrm{ha}^{-1}$, the acidity correction reaction was slower, producing gentle increases in $\mathrm{Ca}, \mathrm{Mg}, \mathrm{V}$ and $\mathrm{pH}\left(\mathrm{CaCl}_{2}\right)$. This is due to the coarser granulometry of the limestone used (82\% RTNP), causing the dissolution to be gradual and enhanced by the existence of high acidity. In addition, acidity correction depends on a chemical equilibrium reaction between the products $\left(\mathrm{Ca}^{2+}\right.$ and $\left.\mathrm{OH}\right)$ that cause the limestone dissolution rate to decrease. Thus, at lower doses, the existence of higher acidity stimulates limestone dissolution. At higher doses, however, the reaction is slower, increasing the residual effect of liming (Kaminski et al., 2005).

In general, forage grasses are more adapted to soil acidity than legumes or even grain-producing grasses (CQFS-RS/SC, 2004). The results of this work show a significant effect of liming up to the recommended dose $\left(8.50 \mathrm{t} \mathrm{ha}^{-1}\right)$ to achieve a $\mathrm{pH}$ (water) of 5.5 after 5 harvests. Notwithstanding, the choice of the limestone dose to be applied should consider the soil and crop conditions, the residual effect and the financial condition of the producer. Under conditions of low available capital, half the dose (4.25 tha-1) could be applied to reach a pH of 5.5, since this dose already presents adequate conditions such as base saturation around $60 \%$ and low $\mathrm{Al}^{3+}$. It should be noted that the use of half the dose would reduce the residual effect of liming and, because it is a perennial plant, future applications may be applied on the surface.

\section{Conclusions}

In the Tifton establishment, limestone application at half and full dose to achieve a pH (water) of 5.5 increased pasture productivity.

The use of limestone increased the values of $\mathrm{pH}\left(\mathrm{CaCl}_{2}\right)$, base saturation, exchangeable calcium and magnesium, and decreased the levels of exchangeable aluminum and copper available in the soil.

The application of copper, zinc and boron provided greater availability of micronutrients in the soil, but did not influence the dry matter production of Tifton.

\section{References}

Almeida JA, Ernani PE, Maçaneiro KC (1999) Recomendação alternativa de calcário para solos altamente tamponados do extremo sul do Brasil. Ciência Rural 29:651-656.

Bandinelli DG, Gatiboni LC, Trindade JPP, Quadros FLFQ, Flores JPC, Brunetto G, Saggin A (2005) Composição florística de pastagem natural afetada por fontes de fósforo, calagem e introdução de espécies forrageiras de estação fria. Ciência Rural 35: 84-91.

Barber SA. Soil Nutrient Bioavalibility (1984). In: Barber SA Rizhosphere microorganisms and root hairs. Indiana: John Wiley \& Sons ed. p.160-178.

Brunetto G, Miotto A, Ceretta CA, Schmitt DE, Heinzen J, Moraes MP, Canton L, Tiecher TL, Comin JJ, Girotto E (2014) Mobility of copper and zinc fractions in fungicide-amended vineyard sandy soils. Archives of Agronomy of Soil Science 60: 609-624. 
CQFS-RS/SC - Comissão de Química e Fertilidade do Solo (2004) Manual de adubação e calagem para os Estados do Rio Grande do Sul e Santa Catarina. 10a ed. Porto Alegre: Núcleo Regional Sul/UFRGS,400p.

EPAGRI - Empresa de Pesquisa Agropecuária e Extensão Rural de Santa Catarina (2013). Síntese anual da agricultura de Santa Catarina 2012-2013. Florianópolis: EPAGRI, 118p.

Ernani PR, Bayer C, Maestri L (2002) Corn yield as affected by liming and tillage system on an acid Brazilian Oxisol. Agronomy Journal 94: 305-359. doi:10.2134/agronj2002.0305

Ernani PR, Steckling C, Bayer C (2001) Características químicas de solo e rendimento de massa seca de milho em função do método de aplicação de fosfatos, em dois níveis de acidez. Revista Brasileira de Ciência do Solo 25:939-46. doi:10.1590/S010006832001000400017

Ernani PR, Almeida JA (1986) Comparação de métodos analíticos para avaliar a necessidade de calcário dos solos do estado de Santa Catarina. Revista Brasileira de Ciência do Solo 10:43-50.

FAO, ISRIC, ISSS (1998) World Reference Base of Soil Resources. World Soil Resources Reports 84 . FAO, Rome, Italy.

Fonseca AF, Caires EF, Barth G (2010) Extraction methods and availabilityof micronutrientes for wheat under a no-till system with a surface application of lime. Scientia Agrícola 67(1): 60-70.

Garcia G, Peñas JM, Manteca JI (2008) Zn mobility and geochemistry in surface sulfide mining soils from SE Spain. Environmental Research 106 (3): 333-339. doi:10.1016/j.envres.2007.04.008

Gatiboni LC, Kaminski J, Pellegrini JBR, Brunetto G, Saggin A, Flores JPC (2000) Influência da adubação fosfatada e da introdução de espécies forrageiras de inverno na oferta de forragem de pastagem natural. Pesquisa Agropecuária Brasileira 35(08):1663-1668.

Impa SM, Jhnson-Beebout SE (2012) Mitigating zinc deficiency and achieving high grain $\mathrm{Zn}$ in rice through integration of soil chemistry and plant physiology research. Plant Soil 361:3-41. doi:10.1007/s11104012-1315-3
Kaminski J, Santos DR, Gatiboni LC, Brunetto G, Silva LS (2005) Eficiência da calagem superficial e incorporada precedendo o sistema plantio direto em um Argissolo sob pastagem natural. Revista Brasileira de Ciência do Solo 29:573-580.

Lopes AS (1999) Micronutrientes: Filosofias de aplicação e eficiência agronômica. São Paulo: ANDA; 1999. (Boletim técnico 8).

Matos AT, Freitas WS, Martinez MA, Tótola MR, Azevedo AA (2010). Tifton grass yield on constructed wetland used for swine wastewater treatment. Revista Brasileira de Engenharia Agrícola e Ambiental 14:510516. doi: 10.1590/S1415-43662010000500008

Nascimento CWA, Melo ÉEC, Nascimento RSMP, Leite PVV (2007) Effect of liming on the plant availability and distribution of zinc and copper among soil fractions. Communications in Soil Science and Plant Analysis doi.org/10.1080/00103620601174643

38:545-560.

Prado RDM, Barion RD (2009) Efeitos da calagem na nutrição e produção de massa seca do capim Tifton 85. Pesquisa Agropecuária Tropical 39(03):218-224, 2009.

SAS Institute Inc®. SAS Ver. 9.1.3. Cary: SAS Institute; 2003.

Silva CA, Vale FR (2000) Disponibilidade de nitrato em solos brasileiros sob efeito da calagem e de fontes e doses de nitrogênio. Pesquisa Agropecuária Brasileira 35:2461-2471.

Tedesco MJ, Gianello C, Bissani CA, Bohnen H, Volkweiss SJ (1995) Análises de solo, planta e outros materiais. $2^{\mathrm{a}}$.ed. Porto Alegre: Universidade Federal do Rio Grande do Sul.

Tiecher T, Oliveira LB, Rheinheimer DS, Quadros FLF, Gatiboni LC, Brunetto G,Kaminski J (2013) Phosphorus application and liming effects on forage production, floristic composition and soil chemical properties in the Campos biome, southern Brazil. Grass Forage Science 69: 567-579. doi: 10.1111/gfs.12079

Volpe E, Marchetti ME, Macedo MCM, Rosa EJ (2008) Renovação de pastagem degradada com calagem, adubação e leguminosa consorciada em Neossolo Quartzarênico. Acta Scientiarum Agronomy 30:131138. doi: 10.4025/actasciagron.v30i1.1162 